\title{
METODOLOGI TAFSIR
}

\author{
Aldomi Putra \\ Dosen Ulum Alquran dan Tafsir STAI YASTIS Padang
}

\begin{abstract}
Abstrak
Tulisan ini tentang metode penulisan, yang menitik beratkan pada metodologi/metode-metode tafsir, dan metode penelitian tafsir. Dalam kajian tafsir (interpretation) terhadap teks Alquran, dibutuhkan seperangkat pengetahuan tentang penafsiran Alquran sehingga tidak bisa dilakuan oleh banyak orang. Mannā' Khālil Qathān misalnya memberikan persyaratan yang begitu ketat (baca; Qathān). Di samping memiliki kriteria bagi mufassir terhadap teks, yang paling penting lagi adalah ketepatan dalam mengunakan metode dalam penafsiran Alquran. Metode-metode penafsiran terhadap teks Alquran meliputi; sumber, intensitas, langkah dan perspektif/corak (laun). Metode tafsir dari segi sumber terbagi dua yaitu bi al-Ma'tsur dan bi al-Ra'yi. Metode tafsir dari segi intensitasnya terbagi kepada ijmali dan tahlili. Metode tafsir dari segi langkah terbagi pada muqarran, maudhu'I,dan tartib suar. Dan metode tafsir dari segi perspektif terbagi kepada fiqh, falsafi, sufi, 'ilmi dan lain sebagainya. Penelitian terhadap tafsir juga membutuhkan metode. Metode penelitian tafsir lebih cenderung menggunakan metede kualitatif, ketimbang metode kuantitatif.
\end{abstract}

Kata Kunci: Metode, Ijmâlî, Tahlîlî, Muqâran, Maudhû'̂̂, dan Kualitatif

\section{Pendahuluan}

Istilah metode-metode dalam tulisan ini, juga dipahami dengan methodology. Jika diperhatikan kata methodology berasal dari dua kata yaitu "metode" dan "logi". Kata 'metode' berasal dari bahasa Yunani, yaitu "methodos", yang juga tersusun terdiri dari dua terma, yaitu "meta" bermakna menuju, melalui, mengikuti, dan term "hodos" bermakna jalan, perjalanan, dan cara atau arah. ${ }^{1}$ Abu Hilāl al'Askar sebagaimana dikutip oleh

\footnotetext{
${ }^{1}$ Supiana dan M.Karman, Ulumul Qur'an dan Pengenalan Metodologi Tafsir, (Bandung: Pustaka Islamika, 2002), cet.I, hal. 302, lihat juga Fuad Hasan dan Koentjaraningrat, Beberapa asa Metodologi Ilmiah, Jakarta: Gramedia, 1977, hal. 16
}

Thalāl al-Hasan, ia mengatakan metode (manhaj) dilihat dari sisi bahasa adalah cara yang jelas. ${ }^{2}$ Sementara, kata "logi" terambil dari istilah Yunani, "logos", yang berarti ilmu. Dengan demikian, pengertian sederhana tentang metodologi adalah ilmu tentang cara untuk mengerjakan atau melakukan sesuatu. Dalam bahasa Inggris, metodologi ditulis dengan "methodology". Sementara, dalam bahasa Arab, metodologi dapat diterjemahkan dengan kata "thariqah" dan "manhaj". Dalam bahasa Indonesia, metodologi berarti cara yang

2 Thalāl al-Hasan, Manāhij Tafs $r$ alQur'ān min abhās al-marja' al-d n Al-Sayyid Kamāl al-Haidar, t.t., t.th., hal. 24. 
teratur dan terpikir baik-baik untuk mencapai maksud (dalam ilmu pengetahuan dan sebagainya); cara kerja yang bersistem untuk memudahkan pelaksanaan suatu kegiatan guna mencapai sesuatu yang ditentukan. ${ }^{3}$ Jika "metode" diterjemahkan dengan suatu cara terpenting untuk mencapai tujuan yang telah ditetapkan, maka metodologi dapat diartikan dengan ilmu yang mempelajari suatu cara terpenting untuk mencapai tujuan yang telah ditetapkan.

Ahmad Syukri Shaleh mendefinisikan metodologi sebagai wacana tentang cara melakukan sesuatu yang disebut dalam bahasa Arab disebut dengan manhaj/ minhaj, seperti diungkap dalam QS. Al-Maidah (5): ayat 48 (yaitu: لكل جعلنا منكم شرعة و منهاجا ), yang berarti "jalan yang terang". 4 Supiana dan M. Karman menjelaskan, metodologi tafsir adalah cara yang sistematis untuk mencapai pemahaman yang benar tentang maksud Allah SWT. dalam Alquran, baik yang didasarkan pada pemakaian sumbersumber penafsirannya, sistem penjelasan tafsir-tafsirnya, keluasan penjelasan tafsirnya, maupun yang didasarkan pada sarana dan sistematika ayat yang ditafsirkannya. ${ }^{5}$

\footnotetext{
${ }^{3}$ Nasaruddin Baidan, Metodologi Penafsiran al-Qur'an, (Yogyakarta: Pustaka Pelajar, 2002), cet ke-I, hal. 54. Lihat juga Tim Penyusun Kamus Pusat Pembinaan dan Pengembangan Bahasa Departemen Pendidikan dan Kebudayaan, Kamus Besar Bahasa Indonesia, (Jakarta: Balai Pustaka, 1994), cet ke-2, hal. 652

${ }^{4}$ Ahmad Syukri Saleh, Metodologi Tafsir al-Qur'an Kontemporer Dalam Pandangan Fazlur Rahman, (Jambi: Sultan Thaha Press, 2007) cet ke-2, hal. 39.

${ }^{5}$ Supiana dan M.Karman, Ulumul Qur'an dan Pengenalan Metodologi Tafsir,... hal. 302
}

Dari penejelasan di atas, tulisan ini mengunakan istilah metode dan metode-metode, karena tulisan ini akan menjelaskan beberapa metode dalam penafsiran, yang meliputi metode ijmâlî (secara global), metode tahlîlî (analitis), metode muqâran (metode komparasi), dan metode maudhî̀ $\hat{\imath}$ (metode tematik), serta metode hermeneutika. Setelah menjelaskan metode-metode dalam penafsiran dalam tulisan ini juga akan dijelaskan metode penelitian terhadap tafsir itu sendiri.

\section{Metode-Metode Tafsir}

Kalimat metodologi tafsir adalah kalimat majemuk yang terambil dari dua kata, yaitu "metodologi" dan "tafsir". Karena itu, untuk memahami istilah "metodologi tafsir" mesti berangkat dari penguraian kedua terma tersebut. Terma metodologi secara bahasa berasal dari dua kata, yaitu "metode" dan "logi". Kata metode berasal dari bahasa Yunani, yaitu "methodos", yang juga tersusun terdiri dari dua terma, yaitu "meta" yang bermakna menuju, melalui, mengikuti, dan term "hodos" yang bermakna jalan, perjalanan, dan cara atau arah. ${ }^{6}$ Maka, metodologi dapat diartikan dengan "cara untuk melakukan sesuatu". Sementara, kata "logi" terambil dari istilah Yunani, "logos", yang berarti ilmu. Dengan demikian, pengertian sederhana tentang metodologi adalah ilmu tentang cara untuk mengerjakan atau melakukan sesuatu. Dalam bahasa Inggris, metodologi ditulis dengan "methodology". Sementara, dalam

\footnotetext{
${ }^{6}$ Supiana dan M.Karman, Ulumul Qur'an dan Pengenalan Metodologi Tafsir, (Bandung: Pustaka Islamika, 2002), cet.I, hal. 302
} 
bahasa Arab, metodologi dapat diterjemahkan dengan kata "thariqah" dan "manhaj". Dalam bahasa Indonesia, metodologi berarti cara yang teratur dan terpikir baik-baik untuk mencapai maksud (dalam ilmu pengetahuan dan sebagainya); cara kerja yang bersistem untuk memudahkan pelaksanaan suatu kegiatan guna mencapai sesuatu yang ditentukan.

Membincangkan metodologi tafsir/metode-metode tafsir, tidak luput dari segi sumber, intensitas, langkah, dan praktik/corak dalam menafsirkan Alquran. Berikut ini dijelaskan metode yang mencakup ke empat segi tersebut.

\section{Metode Tafsir dari Segi Sumber}

Berdasarkan sumbernya, tafsîr dapat dibagi menjadi dua yaitu tafsîr bi al-ma'tsûr dan tafsîr bi al-Ra'yi.

a. Tafsîr bi al-Ma'tsûr/ Manqûl

1) Pengertian Tafsîr bi al-Ma'tsûr

Terkait dengan poin ini ada tiga istilah yang memiliki makna sama yang sering dipakai, yaitu: bi al-ma'tsûr, bi al-manqûl dan bi al-Riwâyah. Kata bi al-ma'tsûr dipakai sebagai antonim $b i$ al-Ra'yi, Kata bi al-manqûl/'naqli dipakai sebagai antonim bi ma'qûl/ 'aqli dan bi al-Riwâyah berlawanan dengan bi al-Dirâyah. Tafsîr bi alma'tsûr secara bahasa terdiri dari dua kata yaitu tafsîr dan ma'tsûr. Kata ma'tsûr merupakan isim maf'ûl dari kata (atsran) dengan makna manqûl (sesuatu yang disampaikan dari

7 Nasaruddin Baidan, Metodologi Penafsiran al-Qur'an, (Yogyakarta: Pustaka Pelajar, 2002), cet ke-I, hal. 54. Lihat juga Tim Penyusun Kamus Pusat Pembinaan dan Pengembangan Bahasa Departemen Pendidikan dan Kebudayaan, Kamus Besar Bahasa Indonesia, (Jakarta: Balai Pustaka, 1994), cet ke-2, hal. 652. seseorang pada yang lainnya). Jika dikatakan أثر الحديث maka maksudnya

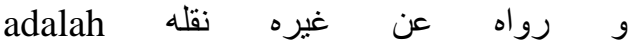
(menyampaikan atau meriwayatkannya dari orang lain). ${ }^{8}$

Sedangkan adalah

(khabar yang diriwayatkan atau sunnah berupa peninggalan) ${ }^{9}$. Di dalam Mu'jam al-Washît itu الحديث المروي، sendiri diartikan dengan (hadîts yang diriwayatkan, atau sesuatu yang diterima orang belakangan/khalâf dari orang-orang terdahulu/salâf). Ini juga sejalan dengan yang ditulis Ibn Manzhûr yaitu: يخبر الناس به بعضهم بعضا، أي ينقله disampaikan antara sesama manusia atau sesuatu yang diterima orang belakangan/khalâf dari orang-orang terdahulu/salâf). ${ }^{10}$ Maka dapat didefenisikan sebagai istilah/penyebutan untuk sesuatu yang diterima khalâf dari salâf baik berupa ilmu, hadîts, riwayat, dan lain sebagainya. Jadi dinamai dengan nama ma'tsûr (dari kata atsâr yang berarti sunnah, hadîts, jejak, peninggalan) karena dalam melakukan penafsiran seorang mufassir menelusuri jejak atau peninggalan masa lalu dari generasi sebelumnya terus sampai kepada Nabi Saw. Adapun manqûl merupakan berasal dari kata ( ينقل- - ), من طريق الرواية أو السماع yang berarti

${ }^{8}$ Sebagaimana yang dikutip oleh Shâlah abd al-Fattâh al-Khâlidiy dari Mu'jam alWashît. Lebih lanjut lihat Shâlah abd al-Fattâh al-Khâlidiy (selanjutnya disebut dengan alKhâlidiy), Ta'rif al-Dârisîn bi Manâhij alMufassirîn, (Damaskus: Dar al-Qalam, 2002), hal. 199.

${ }^{9}$ di dalam lisan al-'Arab diartikan dengan (sesuatu yang disampaikan), lihat. Ibn manzhur, Lisan al-Arab, Qahirah: Dar alMa'arif, t.th, hal. 25.

${ }^{10}$ Ibn manzhur, Lisan al-Arab...hal. 25. 
(sesuatu yang diketahui lewat cara periwayatan atau proses mendengar)

Sedangkan secara terminologi tafsîr bi al-ma'tsûr adalah sebagaimana yang didefenisikan para ahli berikut ini: Muhammad Husain al-Dzahabiy mendefinisiakan;

$$
\begin{aligned}
& \text { ما جاء في القرأن نفسه من البيان وتفصيل لبعض }
\end{aligned}
$$

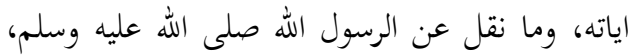

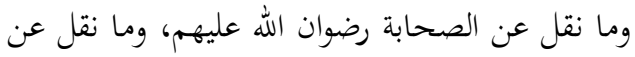

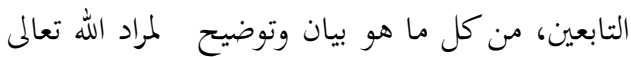

$$
\begin{aligned}
& \text { من نصوص كتاب الكريم' }
\end{aligned}
$$

Sesuatu yang berasal dari al-Qur'ân berupa penjelasan atau uraian bagi sebahagian ayatnya, atau sesuatu yang berasal dari Rasul (hadîts, penulis), atau yang berasal dari para sahabat ra dan dari tabi'in, selama (semua itu) berupa penjelasan atau uraian mengenai maksud Allâh Swt dari nash kitab al-Qur'ân.

Muhammad 'Abd al-'Azhîm alZarqâniy dan Muhammad 'Âliy alShabûniy meberikan pengertian;

$$
\begin{aligned}
& \text { ما جاء في القرأن، أو السنة، أو كلام الصحابة، بيانا } \\
& \text { لمراد الله تعالى باء }
\end{aligned}
$$

\footnotetext{
${ }^{11}$ Muhammad Husain al-Dzahabiy, alTafsîr wal-Mufassirûn, Qahirah: Maktabah alWahbah, 1995, Jilid II, hal. 163, Defenisi ini juga dirujuk oleh Muhammad Shafa Ibrâhîm Haqqiy, sehingga ia mendefenisikannya sebagai berikut:

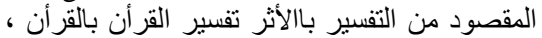

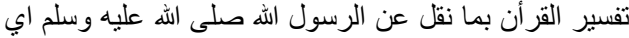

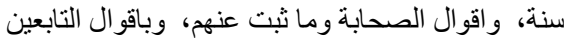

Muhammad Shafa Ibrâhîm Haqqiy, 'Ulûm al-Qur'ân min Khilâl Muqaddimah alTafsîr, Beirut: Maktabah al-Risâlah, 2004, juz. III, hal. 227.

${ }^{12}$ Lihat Muhammad abd al-'Azhim alZarqâniy, Manâhil al-'Irfân fi 'Ulûm alQur'an, Beirut: Dar al-Kitâb al-'Arabiy, 1995, Juz. II, hal. 12, atau lihat juga Muhammad 'Aliy al-Shabûniy, Al-Tibyân fi 'Ulum al-
}

Sesuatu yang berasal dari al-Qur'ân, atau Sunnah maupun perkataan sahabat yang menjelaskan maksud Allâh Swt (di dalam al-Qur'ân, penulis)

Menurut Hasan Yunus 'Ubaidu definisinya adalah;

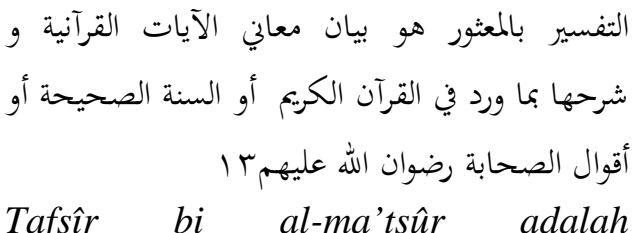
menjelaskan makna ayat-ayat AlQur'an dan syarahnya dengan AlQur'an Al-Karîm atau dengan sunnah yang shahih atau dengan perkataan sahabat r.a.

Menurut Mana' al-Qatthân

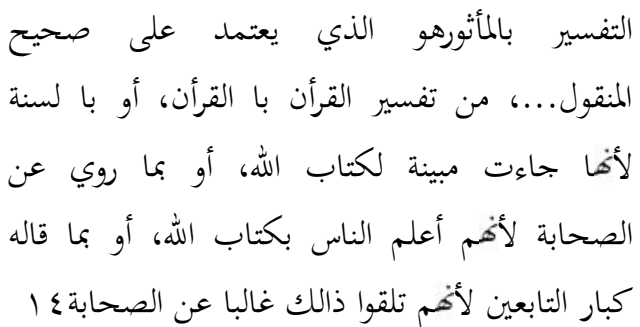

Tafsîr bi al-ma'sûr adalah tafsîr yang berdasarkan pada kutipankutipan/riwayat yang shahîh ..., berupa tafsîr al-Qur'ân dengan al-Qur'ân, atau dengan Sunnah (karena Sunnah berfungsi sebagai penjelasan bagi kitab Allâh), atau dengan riwayat yang berasal dari para sahabat (karena mereka termasuk orang yang paling mengerti dengan kitab Allâh), atau dengan perkataan para tabi'in besar,

Qur'an, Jakarta: Dar al-Kutub al-'Ilmiyah, 2003, hal. 67.

${ }^{13}$ Hasan Yunus 'Ubaidu, Dirâsât wa Mabâhis fî̀ Târîkh wa Manâhij al-Mufasirîn Mesir : Markazd al-Kitâb linnasyar, t.th, hal. 20.

${ }^{14}$ Mana' Khalîl al-Qaththân, Mabâhits fi 'Ulûm al-Qur'ân, Al-Qahirah: Maktabah Wahbah, 2007, hal. 338. 
karena mereka senantiasa mendapatinya dari para sahabat.

Jika dicermati definisi-definisi di atas, maka terdapat beberapa persamaan, dan perbedaan. Tetapi meski demikian penulis dapat dirumuskan bahwa; Tafsîr bi alma'tsûr adalah tafsîr yang berdasarkan riwayat yang shahîh $\underline{\text {. Terutama dengan }}$ Mana' Khalîl al-Qaththan, ia telah mewanti-wanti pendapat banyak kalangan yang meragukan tafsîr bi alma'tsûr karena banyak dipengaruhi oleh riwayat isrâiliyât dan riwayat yang dha'îf. Maka baginya sesuatu yang dikatakan dengan tafsîr bi alma'tsûr mestilah bersumber dari riwayat yang shahîh $\underline{h} .^{15}$ Penafsiran Tafsîr bi al-ma'tsûr dapat berupa alQur'ân, Sunnah dan perkataan sahabat. Khusus dengan perkataan tabi'in terdapat perbedaan di kalangan ulama.

Singkatnya tafsîr bi al-ma'tsûr adalah tafsîr yang berdasarkan pada riwayat yang shahîh $\underline{h}$, berupa tafsîr alQur'ân dengan al-Qur'ân, dengan Sunnah, atau dengan riwayat yang berasal dari para sahabat, serta menghindari pembicaraan yang tidak terkait lansung dengan penafsiran, selama tidak ada riwayat yang shahîh $\underline{h}$ tentang itu.

2) Sumber-sumber tafsîr bi alMa'tsûr

Di dalam menentukan sumber tafsîr bi al-ma'tsûr para ulama berbeda pendapat, di antaranya al-Rûmiy menjadikan sumber tafsîr bi al-ma'tsûr itu menjadi 4 macam yaitu: al-Qur'ân, Sunnah Nabi, Perkataan sahabat dan

${ }^{15}$ Hal ini pulalah nantinya yang sangat ditekankan oleh al-Khalidi ketika membahas mengenai sumber-sumber tafsir bi al-ma'tsur. Ini akan penulis jabarkan pada poin berikutnya. penafsiran tabi'in $^{16}$. Al-Khâlidiy menjadikan sumber tafsîr bi al-ma'tsûr menjadi 5 macam dengan tidak memasukkan al-Qur'ân- yaitu: Hadîts Shahîh yang marfû́ kepada Nabi, Perkataan shahîi $h$ sahabat yang terkait dengan penafsiran ayat al-Qur'ân, Perkataan tabi'in yang shahîh, alqirâ'ât al-syâdz dan al-qirâ'ât altafsîriah.

3) Posisi dan Hukum Tafsîr bi alMa'tsûr

Tafsîr bi al-Ma'tsûr wajib diikuti dan diambil jika terbukti shahîh $\underline{h}$. Karena terjaga dari penyelewengan makna kitab Allâh. Ibnu Jarîr berkata, "Ahli tafsîr yang paling tepat mencapai kebenaran adalah yang paling jelas hujjah-nya terhadap sesuatu yang dia tafsir-kan dengan dikembalikan tafsirnya kepada Rasûl Allâh dengan khabar-khabar yang tsâbit dari beliau dan tidak keluar dari perkataan salâf."

4) Qaidah Tafsîr Terkait Tafsi bi al-ma'tsur

Terkait dengan tafsîr bi alma'tsur terdapat beberapa kaidah yang ditulis oleh al-Khâlidiy yaitu: a) تفسير القرأن بالقرأن هو الأساس لما بعده من التفسير (tafsîr al-Qur'ân dengan alQur'ân adalah dasar bagi tafsîr bi al-

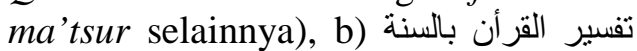
يلي تفسير القرأن بالقرأن في المنزلة والأهمية (dari sisi kedudukan dan arti pentingnya, tafsîr al-Qur'ân dengan Sunnah berada setelah tafsîr al-Qur'ân dengan al-Qur'ân). Dari dua kaidah ini dapat dipahami bahwa tafsîr yang paling utama adalah tafsîr al-Qur'ân dengan al-Qur'ân (ini bisa dalam bentuk bayân al-mujmâl, taqyîd almuthlaq, takhshîh al-'âm, bayân almantuq dengan al-mafhûm, dan

${ }^{16}$ Fahd 'Abd al-Rahmân Sulaimân alRûmiy, Buhust fi Ushul al-Tasfsir, t.tp, Maktabah Al-Taubah, t.th, hal. 73-78 
berbagai bentuk lainnya), kemudian alبيان الرسول اله ( ب) ân dengan Sunnah., c) صلى الله عليه و سلم لأية و تفسيره لها مقدم على (Penjelasan dan penafsiran Rasul terhadap suatu ayat diutamakan daripada penjelasan apapun) Dari Kaidah ini dapat dipahami bahwa apabila telah ada keterangan Nabi terhadap makna suatu ayat, maka keterangan lain tidak dapat diperpegangi jika menyalahi keterangan Nabi ini., d)

(Pendapat sahabat mengenai tafsîr lebih didahulukan dari pada pendapat orangorang [belakangan] setelahnya.), e)

التابعي في التفسير مقدم على قول من بعد (Pendapat tabi'in mengenai tafsîr lebih didahulukan dari pada pendapat orangorang [belakangan] setelahnya). Kaidah 1, 2, 4 dan 5 di atas menjelaskan bahwa sumber tafsîr yang paling utama adalah al-Qur'ân, kemudian al-Sunnah, kemudian qaul al-shahabah dan kemudian qaul al-tabi'in. Maka penafsiran sunnah pada dasarnya tidak boleh menyalahi al-Qur'ân, qaul alshahabah tidak boleh menyalahi sunnah, dan qaul al-tabi'in tidak boleh menyalahi qaul al-shahabah serta pendapat mufassir berikutnya tidak boleh menyalahi qaul al-tabi'in dan sumber tafsîr di atasnya., f) لا يؤخذ (Tafsîr bi al-ma'tsur pada dasarnya tidak akan digunakan kecuali setelah dipastikan [ke-shahîh-annya] dan pen-takhrîjannya). Sesuai dengan kaidah ini, tafsîr bi al-ma'tsûr haruslah dinilai kualitas sanadnya, sebagai mana hadîts Nabi yang lain. Menurut penulis, Kaidah ini menjadi jawaban terhadap banyaknya kemungkinan yang menyebabkan lemahnya tafsîr bi al-ma'tsur., ${ }^{17} \mathrm{~g}$ )

17 Menurut al-Shabûniy, ada 4 sebab
الجمع بين الأقوال المختلفة عن الصحابة و التابعين (Perbedaan pendapat antara tabi'in dan sahabat diselesaikan secara aljam'u/kompromikan) Berdasarkan kaidah ini dapat dipahami bahwa tafsîr bi al-ma'tsur -antara perkataan sahabat dan tabi'în- selama memiliki jalur sanad yang shahîh, tidak akan bertentangan, dan yang ada hanyalah tanawwu'/fariasi penafsiran. Maka ketika ada perbedaan diselesaikan dengan cara mengkompromikan keduanya, dan jika tidak bisa dilakukan dengan tarjîh., h) عدم اعتماد الإسر ائيليات الا ما صح شاهده عندنا (isrâ'iliyât ${ }^{18}$ tidak dapat diperpegangi kecuali memiliki syahid yang shahîh) Kaidah ini menunjukkan kehati-hatian para mufassir terhadap cerita isrâiliyât. Dan ini merupakan wujud dari perwujudan hadîts Nabi terkait ahli al-kitâb: ע تصدقوا أهل الكتاب ولا تكذبواهم، وقولوا أمنا با الله وما أنزل علينا

\section{b. Tafsîr bi al-Ra'yi/ al-Ma'qul \\ Secara bahasa kata} رأى، برى merupakan mashdar dari kata yang di dalam pemakaiannya digunakan untuk penglihatan mata. Selain untuk istilah penglihatan mata,

yang menyebabkan dha'îf-nya tafsir bi alma'tsûr yaitu: a. Tercampurnya antara riwayat yang shahih dengan yang tidak, b. adanya riwayat isrâ'iliyat, c. adanya usaha kelompok mazhab yang menisbahkan perkataan/pendapat mereka kepada para sahabat nabi, dan $d$. Adanya usaha dari kaum zindiq untuk merusak agama dengan menisbahkan perkataan dusta kepada nabi dan para sahabat ataupun tabi'in. 'Aliy al-Shabûniy, Al-Tibyân fi 'Ulum alQur'an..., h. 70-71

${ }^{18}$ Isrâiliyât adalah istilah yang diberikan ulama untuk riwayat atau kisah masa lalu yang tidak berasal dari Islam, tetapi justru didapatkan dari berita ahl al-kitab (Yahudi dan Nasrani). 
ia juga dapat digunakan terkait dengan (keyakinan), تدبير(pandangan) dan تفكير (pemikiran). Menurut Husain alDzahabiy juga dapat dipakai untuk makna قياس (ijtihâd) dan فنتهاد (qiyas). Selain dengan istilah ra'yi, tafsîr ini juga dikenal dengan istilah 'aqli atau nazhri. Disebut dengan tafsîr 'aqli karena memang di dalam penafsirannya, seorang mufassîr sangat memberdayakan akal dan fikirannya. Sedangkan dinamakan dengan nazhri karena memang tafsîr ini merupakan hasil dari penelitian yang mendalam. ${ }^{20}$ Sedangkan menurut Istilah terdapat beberapa defenisi yang diberikan ulama yaitu: Menurut Mana' Khalîl alQaththan;

$$
\begin{aligned}
& \text { هو ما يعتمد فيه المفسر في بيان المعنى على فهمه }
\end{aligned}
$$

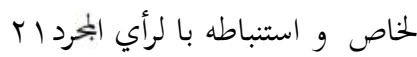

Yaitu tafsîr yang mufassîrnya di dalam menjelaskan makna hanya mengandalkan pemahaman dan mengistinbath-kannya dengan menggunakan logika semata.

Kemudian Mana' Khalîl alQaththan menambahkan keterangan terkait defenisi ini. Menurutnya yang dimaksud logika semata adalah logika yang pemahamannya tidak sejalan dengan nilai syari'at, dan biasanya dilakukan oleh ahli bid'ah. Menurut al-Rûmiy mendefinisikan

$$
\text { r r هو (هبارة عن تفسير القرأن بالإجتهاد }
$$

Yaitu istilah untuk penafsiran Alquran dengan menggunakan ijtihâd.

Menurut al-Dzahabiy

\footnotetext{
${ }^{19}$ Al-Khâlidî, Ta' rif al-Dârisîn bi

Manâhij al-Mufassirîn..., hal. 413

${ }^{20}$ Al-Khâlidî, Ta'rif al-Dârisîn bi

Manâhij al-Mufassirîn...,, hal. 413.

351.

${ }^{21}$ Mana' Khalîl al-Qaththân,..., hal.

${ }^{22}$ Fahd 'Abd al-Rahmân Sulaimân alRûmiy, Buhust fi Ushul al-Tasfsir ..., hal. 78 .
}

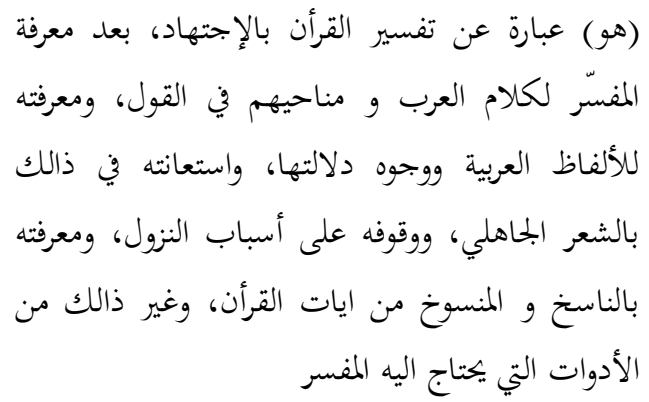

Yaitu istilah untuk penafsiran Alquran dengan menggunakan ijtihâd, setelah seorang mufassîr tersebut menguasai kalam Arab dan pemakaiannya di dalam perkataan, mengetahui bahasa Arab, dan wujuh dilalahnya, serta usahanya untuk merujuk kepada sya'ir Arab jahiliyah, asbâb al-nuzûl, mengetahui nâsikh dan mansûkh, dan ilmu-ilmu lain yang dibutuhkan oleh para mufassîr

Jika kita mencermati defenisi demi defenisi, antara satu defenisi dengan lainnya tidak ada yang sama. Menurut penulis defenisi pertama tidak bisa dikatakan sebagai defenisi tafsîr bi $a l-r a ' y i$, dan tepatnya itu merupakan defenisi tafsîr bi al-ra'yi al-madzmûm (yang tercela), sedangkan defenisi yang ke tiga dan yang ke empat, itupun tidak bisa dikatakan sebagai defenisi tafsîr bi $a l-r a$ 'yi, dan itu hanya dapat dikatakan sebagai defenisi tafsîr bi al-ra'yi almahmûd (terpuji). Maka defenisi tafsîr bi al-ra'yi yang tepat -menurut penulis adalah defenisi yang diberikan oleh alRûmiy. Singkatnya, tafsîr bi al-ra'yi dapat diartikan dengan penafsiran alQur'ân dengan menggunakan ijtihâd, baik berangkat dengan menggunakan ilmu yang terkait dengannya, maupun hanya dengan logika semata.

\section{Metode tafsir dari segi intensitas}

Membincangkan metode-metode tafsir, dari segi intensitasnya terbagi 
dua yaitu metode ijmâlî (secara global), metode tahlîlî (analitis).

\section{a. Ijmâlî}

Secara harfiah, kata Ijmâlî berarti ringkasan, ikhtishar, global dan penjumlahan. Secara istilah metode ijmâlî adalah cara mengemukakan isi kandungan Alquran melalui pembahasan yang bersifat umum (global), tanpa uraian apalagi pembahasan yang panjang dan luas, dan tidak dilakukan secara rinci. ${ }^{23} \mathrm{Al}-$ Farmawiy mendefinisikan tafsir ijmâlî adalah sebagai berikut;

و هو بيان الآيات القرآنية بالتعرض لمعانيها إجمالا و

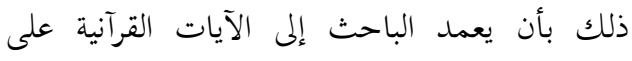

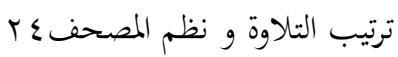

Tafsir ijmâlî adalah menjelaskan ayatayat Alquran dengan mengemukakan makna-maknanya secara global, hal itu dengan cara dimana seorang mufassir membahas ayat-ayat Alquransesuai dengan tertib bacaan dan susunan yang ada dalam mushaf.

Berdasarkan definisi yang telah dikemukakan di atas, maka cara kerja metode ijmâlî adalah menjelaskan makna Alquran, ayat demi ayat secara berurutan yang sesuai dengan ketentuan mushaf dan dilanjutkan dengan menjelaskan makna ayat secara global, yang mudah dipahami oleh para pembaca.

Metode tafsir ijmâlî ini, jika diperhatikan secara historis merupakan metode yang paling pertama hadir dalam sejarah perkembangan metodologi tafsir. Pernyataan ini

${ }^{23}$ Muhammad Amin Suma, Studi Ilmuilmu al-Qur'an 2, (Jakarta: Pustaka Firdaus, 2001), hal. 113.

24 Abd al-Hayy al-Farmawiy, alBidayah fi al-Tafsir al-Maudhu'i, (Kairo: Hadrat al-Gharbiyah, 1977), hal. 43. didasarkan kepada kenyataannya bahwa pada masa Nabi SAW dan para sahabatnya dalam menjelaskan Alquran, bahasa tidaklah menjadi problem dan bukanlah menjadi penghalang dalam memahami Alquran. Ini bukan karena mayoritas sahabat merupakan orang-orang Arab dan ahli dalam bahasa Arab, tetapi para sahabat mengetahui dengan cermat latar belakang turunnya ayat-ayat Alquran (asbâb al-Nuzîl), bahkan para sahabat terlibat langsung dalam situasi dan kondisi umat ketika ayat Alquranturun. ${ }^{25}$

Adapun ciri-ciri metode tafsir ijmāl adalah sebagai berikut: Mufassir langsung menafsirkan Alquran secara garis besar mulai dari awal surat alfātihah sampai akhir surat al-Nās tanpa perbandingan dan penentuan judul, penafsirannya ringkas dan umum, tidak ada ruang untuk mengemukakan pendapat yang serupa, dan sistematika penulisan dan penyajiannya mengikuti urutan dan tertib surat-surat dalam Alquran sehingga maknanya saling berkaitan. ${ }^{26}$

Metode ijmāl sebagai sebuah metode memiliki keistimewaan dalam menafsirkan Alquran. Adapun keistimewaannya adalah menafsirkan Alquran kelihatan sederhana, mudah praktis dan cepat. Termasuk juga keistiewaannya adalah pesan-pesan Alquran mudah ditangkap atau dipahami. $^{27}$ Jika diperhatikan keterangan tersebut, patut juga dikatakan bahwa metode ijmāl merupakan kesederhanaan dalam

\footnotetext{
${ }^{25}$ Syukri Shaleh, Metodologi Tafsir alQur'an Kontemporer,.... hlm. 45-46

26 Nasaruddin Baidan, Metode Penafsiran al-Qur'an.... hlm. 13-14

27 Amin Suma, Studi Ilmu-ilmu alQur'an 2,..... hlm. 115
} 
menafsirkan Alquran, penafsiran dengan menggunakan metode ijmāl terhindar dari israiliyat ${ }^{28}$ dan metode ini juga efektif untuk membentengi pemikiran-pemikiran yang spekulatif. Disamping keistimewaan metode $i j m \bar{a} l$ juga memiliki kelemahan. Adapun yang menjadi kelemahan dari metode ijmâlî ini terletak pada simplistisnya, yang mengakibatkan penafsiran terhadap Alquran menjadi dangkal, yang menjadikan pentujuk Alquran bersifat parsial (tidak komprehensif), dan tidak ada peluang untuk mengemukakan analisis yang memadai. ${ }^{29}$

${ }^{28}$ Usman (Dosen pada Fakultas Syariah IAIN Mataram) Memahami Isrâ'îliyyât Dalam Penafsiran Al-Qur'an dalam Jurnal Ulumuna, Volume XV Nomor 2 Desember 2011), ia menjelaskan Isrâ'îliyyât merupakan istilah yang dinisbahkan pada kata "Isrâ'îll". Kata Isrâ' îl berasal dari bahasa Ibrani yang secara etimologi berarti "hamba Tuhan". Lihat Khalaf Muhammad al-Husaynî, Al-Yahûdiyyah bayn al-Masîhiyyah wa allslâm , Mesir: AlMu'assasah al-Misriyyah al-'Âmmah, 1974, hlm. 14. Kata Isrâ'îl merujuk pada keturunan Nabi Ya'qub as, kemudian juga dikenal dengan nama Yahudi. Lebih lanjut informasi ini bisa dilihat Jalâl al-Dîn al-Mahallî dan Jalâl al-Dîn al-Sayûthî, Tafsîr al-Qur'ân al- 'Azhîm (Beirut: Dâr al-Fikr, t.t.), hlm. 7. Lihat juga, A. J. Weinsinck, "Israil", dalam Houtsma, et.al., Brill's First Encyclopedia of Islam 1913-1936, jilid 3 (Leiden: E. J. Brill, 1987), hlm. 555. Isrâ'îliyyât secara terminology adalah informasi yang berasal dari ahl al-kitâb baik Yahudi maupun Nasrani yang digunakan untuk menjelaskan nash Alquran. Lihat, Musâ'id Muslim 'Abd al-Lâh Alî Ja'far, Asrâr alTathawwur al-Fikr fî alTafsîr, Beirut: Mu'assasah al-Risâlah, 1984, hlm. 120. Ahmad al-Syirbâshî mendefinisikan isrâ' ̂̂liyyât adalah berita yang diselundupkan oleh orang Yahudi, Nasrani, atau pun yang lainnya ke dalam Islam. Lihat Ahmad al-Syirbâshî, Qishshah al-Tafsîr (Beirut: Dâr al-Qalam, 1972), hlm.98.,

29 Amin Suma, Studi Ilmu-ilmu alQur'an 2, h. 115
Dari penjelasan di atas penulis memahami bahwa metode tafsir ijmâlî adalah metode yang paling mudah untuk memahami ayat-ayat Alquran. Disamping itu metode ini memberikan kemudahan kepada siapa saja yang membaca kitab tafsir yang menggunakan metode ijmâlî secara langsung bisa memahami maksud dari ayat-ayat Alquran.

Setelah dijelaskan pengertian metode ijmâlî, kelebihan dan kekurangannya, berikut ini disajikan kitab-kitab tafsir yang menggunakan metode ini, ada beberapa kitab tafsir yang menggunakan metode ijmâlî ini diantaranya:

1) Al-Tafsir al-Farid li AlquranalMajid, kitab ini sebanyak 8 jilid dengan jumlah lebih-kurang 3377 halaman karya Muhammad 'Abd al-Mun'im

2) Marah labib tafsir al-Nawawil tafsir al-unir li Ma'alim al-Tanzil, sebanyak dua Jilid, karangan al'Allamah al-Syaekh Muhammad an-Nawawi al-Jawi al-Bantani (1230-1314 H/ 1813-1879 M)

3) Al-Tafsir al-Wahid karya Muhammad Mahmud Hijazi, sebanyak 3 jilid dengan jumlah halaman 3000 halaman.

4) Tafsir Alquranal-Karim karya Mahmud Muhammad Hadan 'Ulwan dan Muhammad Ahmad Barmiq sejumlah 6 jilid dengan jumlah halaman 3744 halaman.

5) Fath al-Bayan fi Maqashid alQur'an, karya Imam al-Mujtahid, Shiddiq Hasan Khan sekitar 1248 halaman. 
6) Al-Tafsir al-Wasith yang di terbitkan oleh Majma al-Buhu alIslamiyah, dan lain sebagainya. ${ }^{30}$

\section{b. Tahlîlî ( Deskriptif Analisis)}

Kata tahlîlî berasal dari kata hala yang berarti membuka sesuatu. ${ }^{31}$ Tahlîlî tersebut termasuk bentuk infinitive (mashdar) dari kata hallala yang berarti mengurai, menganalisis serta menjelaskan bagian-bagiannya serta fungsinya masing-masing. ${ }^{32}$ Dengan demikian metode tahlili dapat didefinisikan sebagai metode yang berusaha untuk menerangkan makna ayat-ayat Alquran dari berbagai aspeknya, baik berdasarkan urutanurutan ayat atau surah dalam mushaf, dengan memperihatkan kandungan lafadz-lafadznya, munasabah ayatayatnya, hadis-hadis yang berhubungan dengannya, pendapat-pendapat para mufassir terdahulu dan mufassir itu sendiri yang diwarnai oleh latar belakang pendidikan dan keahliannya pada diri mufassir itu sendiri.

Metode tafsir tahlîlî juga disebut dengan metode tajzi' $i$ tampak merupakan metode tafsir yang paling tua usianya. Muhammad Quraish Shihab menegaskan bahwa metode ini lahir jauh sebelum metode maudhu'i. Metode ini dikenal semenjak Tafsir 1Farra' (w. 206 H/821M), atau Ibn Majah (w. $237 \mathrm{H} / 851 \mathrm{M}$ ) atau paling lambat al-Thabari (w. 310 H/ 922 M).

\footnotetext{
${ }^{30}$ Amin Suma, Studi Ilmu-ilmu alQur'an 2, hlm. 114

31 Ahmad bin Faris bin Zakariya, Mu'jam Maqais al-Lughah, (Mesir: 'Isa alBabi al-Habi, 1990), juz II, hlm.20

32 Ibrahim Musthafa, al-Mu'jam alWasith, (Taheran: al-Maktabah al- Islamiyah, t.t), juz II, hlm. 695

33 Amin Suma, Studi Ilmu-ilmu alQur'an 2..., hlm. 110.
}

Cara kerja metode ini adalah bermula dari kosakata yang terdapat pada setiap ayat yang akan ditafsirkan sebagaimana urutan dalam Al-qur'an, mulai dari Surah Al Fatikhah hingga Surah An-Nass, menjelaskan asbabun nuzul ayat ini dengan menggunakan keterangan yang diberikan oleh hadist (bir riwayah), menjelaskan munasabah, atau hubungan ayat yang ditafsirkan dengan ayat sebelum atau sesudahnya, menjelaskan makna yang terkandung pada setiap potongan ayat dengan menggunakan keterangan yang ada pada ayat lain,atau dengan menggunakan hadist Rasulullah SAW ataudengan menggunakan penalaran rasional atau berbagai disiplin ilmu sebagai sebuah pendekatan, dan menarik kesimpulan dari ayat tersebut yang berkenaan dengan hukum mengenai suatu masalah, atau lainnya sesuai dengan kandungan ayat tersebut. $^{34}$

Metode ini juga memiliki keistimewaan (plus) dan kelemahan (minus)nya. Adapun keistimewaan metode tahlîlî ini antara lain adalah terletak pada keluesan dan keutuhannya dalam memahami al-Qur'an, maksudnya dengan metode tahlîlî seseorang diajak untuk memahami Alquranmulai dari awal mushaf (alFatihāh) sampai akhir (surat al-Nās). Juga termasuk keistimewaannya adalah membahas Alquran dengan rung lingkup yang luas, yang meliputi aspek bahasa, sejarah, hukum, dan sebagainya. $^{35}$ Kendatipun demikian bukan berarti metode ini tidak mempunyai kekurangan atau kelemahan, diantra kelemahan metode

\footnotetext{
${ }^{34}$ Abudin Nata, Studi Islam

Komperhesif, Jakarta: Kencana, 2011, hlm.169

35 Amin Suma, Studi Ilmu-ilmu alQur'an 2..., hlm. 112.
} 
tahlîlî adalah kajiannya tidak mendalam, tidak detail dan tidak tuntas dalam menyelesaikan topik-topik yang dibicarakan, termasuk juga kelemahan metode tahlîlî terletak pada jalannya yang terseok-seok (tidak tersistematis) inilah yang dikritik oleh Muhammad Rasyid Ridha. ${ }^{36}$

Kitab-kitab tafsir yang telah menggunakan metode tahlîlî ini sangat banyak diantaranya adalah sebgai berikut.

1) Jami' al-Bayân Ta'wil Ayi alQur'an, 15 jilid dengan jumlah halaman sekitar 7125, karangan Ibn Jarir al-Thabari (w. 310 H/922 M)

2) Tafsir Alquranal-'Azhim, 4 jilid dengan jumlah halaman 2414 halaman, karangan al-Hafizh Imam al-Dinal-Qurai Abi al-Fida' bin Katsir al-Quraisyi al-Dimasyqi (w. 774 H/ $1343 \mathrm{M}$ )

3) Al-Durr al-Mantsur fi al-Tafsir bi al-Ma'tsur karya Jalal al-Din alSuyuthi ( 849-911 H/ 1445-1505 M) berjumlah 18 jilid dengan 56006400 halaman.

4) Adhwa' al-Bayan fi Idhah Alquranbi al-Qur'an, karya Muhammad al-Amin bin Muhammad al-Mukhtar al-Jakani al-Syanqithi dalam 10 jilid dengan 6771 halaman

5) Al-Kasyf wa al-Bayan 'an Tafsir alQur'an, karya Abi Ishaq., dan lain sebagainya. $^{37}$

\section{Metode tafsir dilihat dari segi langkahnya}

Metode tafsir dilihat dari segi langkahnya terbagi pada tiga yaitu,

\footnotetext{
36 Amin Suma, Studi Ilmu-ilmu alQur'an 2..., h. 112-113

37 Amin Suma, Studi Ilmu-ilmu alQur'an 2,..... hlm. 111-112.
}

muqarran, maudhu'I, dan tartib suar. Berikut ini adalah penjelasannya.

a. Muqâran (Komparatif)

Metode tafsir muqâran adalah tafsir yang dilakukan dengan cara membanding-bandingkan ayat-ayat Alquran yang memiliki redaksi berbeda padahal isi kandungannya sama, atau membandingkan antara ayat-ayat yang beredaksi mirip padahal isi kandungannya berlainan. ${ }^{38}$ Termasuk juga ke dalam metode muqâran menafsirkan ayat-ayat Alquran yang kelihatan berlawanan dengan hadis, padahal pada hakikatnya sama sekali tidak ada pertentangan.

Definisi yang ditawarkan di atas cukup representatif kiranya untuk memberikan pemahaman bahwa tafsir muqâran antar ayat merupakan pola penafsiran Alquran untuk ayat-ayat yang memiliki kesamaan redaksi maupun kasus atau berbeda redaksinya, namun kasusnya sama begitu juga sebaliknya. Metode tafsir muqâran ini juga dapat dilakukan dengan cara membandingkan antara aliranaliran tafsir dan antara mufassir dengan mufassir yang lain, kendatipun perbandingan itu pada perbedaan metode yang digunakan oleh mufassir bersangkutan. Dengan demikian, maka bentukbentuk metode penafsiran yang dilakukan dengan muqâran memiliki objek yang luas dan banyak. ${ }^{39}$ Bentuk-bentuk penafsiran tersebut adalah:

1) Membandingkan ayat-ayat Alquranyang memiliki redaksi

38 Amin Suma, Studi Ilmu-ilmu alQur'an 2,.... hlm. 116

39 Amin Suma, Studi Ilmu-ilmu alQur'an 2,.... hlm. 116 
berbeda tetapi maksudnya sama, atau ayat yang memiliki redaksi mirip tetapi maksudnya berbeda. Contohnya adalah sebagai berikut ini.

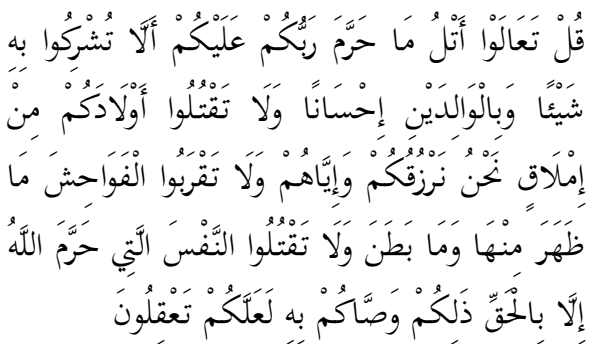

Katakanlah: "Marilah kubacakan apa yang diharamkan atas kamu oleh Tuhanmu Yaitu: janganlah kamu mempersekutukan sesuatu dengan Dia, berbuat baiklah terhadap kedua orang ibu bapa, dan janganlah kamu membunuh anakanak kamu karena takut kemiskinan, Kami akan memberi rezki kepadamu dan kepada mereka, dan janganlah kamu mendekati perbuatanperbuatan yang keji, baik yang nampak di antaranya maupun yang tersembunyi, dan janganlah kamu membunuh jiwa yang diharamkan Allah (membunuhnya) melainkan dengan sesuatu (sebab) yang benar". demikian itu yang diperintahkan kepadamu supaya kamu memahami(nya).[Qs. AlAn'am/6:151]

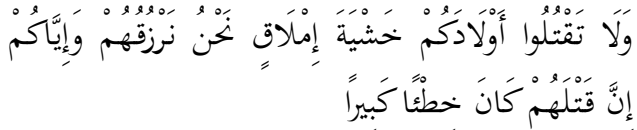

dan janganlah kamu membunuh anak-anakmu karena takut kemiskinan. kamilah yang akan memberi rezki kepada mereka dan juga kepadamu. Sesungguhnya membunuh mereka adalah suatu dosa yang besar.[Qs. AlIsra'/17:31]

Kedua ayat di atas menggunakan redaksi yang berbeda namun maksudnya sama, yaitu sama-sama melarang (mengharamkan) membunuh anak. Hanya saja sasaran dari ayat itu berbeda. Ayat yang pertama sasarannya adalah orang-orang miskin atau fuqara', sedangkan ayat yang kedua sasarannya adalah orang-orang kaya (aghniya') ${ }^{40}$

Redaksi yang berbeda dalam kedua ayat ini tetapi maknanya sama adalah ( takut kelapan) pada surat al-'An'am ayat 151, yang demikian belum tentu terjadi, sedangkan pada redaksi kedua pada surat al-Isra' ayat 31

"إيامهمyang berarti kelaparan telah terjadi. Perbedaan kedua ayat ini terdapat pada redaksi نرزقهم dengan mendahulukan dhamir ghaib yaitu و إياكم وdan mengakhirkan dhamir , sedangkan pada surat al-Isra' خشية redaksi yang digunakan adalah disamping mengakhirkan dhamir ghaib dan mendahulukan dhamir نرزقهمpada . Kata خشية إملاقmenunjukkan bahwa kelaparan telah terjadi, sedangkan maksud pendahuluan dhamir ه dari pada dhamir bertujuan untuk meyakinkan mukhatab (lawan bicara) tentang jaminan Allah terhadap rezki anak disamping juga orang tuanya. ${ }^{41}$

2) Membandingkan ayat Alquran dengan al-Hadist yang terkesan bertentangan padahal tidak. Misalnya;

40 Amin Suma, Studi Ilmu-ilmu alQur'an 2..., hlm. 117.

${ }^{41}$ Amin Suma, Studi Ilmu-ilmu alQur'an 2..., hlm. 117-118. 


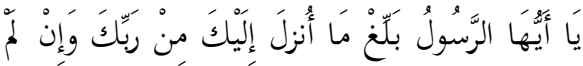

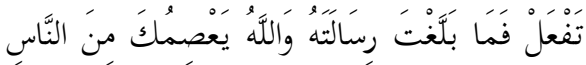

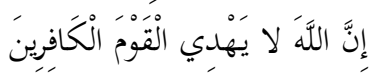

Hai rasul, sampaikanlah apa yang diturunkan kepadamu dari Tuhanmu. dan jika tidak kamu kerjakan (apa yang diperintahkan itu, berarti) kamu tidak menyampaikan amanat-Nya. Allah memelihara kamu dari (gangguan) manusia. Sesungguhnya Allah tidak memberi petunjuk kepada orangorang yang kafir.[Qs. AlMaidah/5:67]

Zahir ayat mengisyaratkan bahwa Allah SWT akan selalu melindungi dan memelihara keselamatan dan jiwa Nabi SAW, baik dari kemungkinan pelukaan maupun pembunuhan yang akan dilakukan oleh musuh-musuh Islam. Namun demikian al-Zarkasi mengatakan ada riwayat shahih yang menginformasikan bahwa ketika terjadi perang uhud ( $3 \mathrm{H} / 625$ M), Nabi SAW sempat terluka oleh musuh yang memeranginya sehingga patah giginya. Jika demikian halnya bagaimana dengan ayat di atas yang menyatakan bahwa Allah akan menjamin keselamatan Nabi SAW. ${ }^{42}$

Untuk menyelesaikan

kontradiktif antara ayat dan hadis yang dimaksud oleh al-Zarkasi, alZarkasi memberikan dua bentuk alternatif: pertama, peristiwa perang uhud terjadi sebelum ayat 67 surat al-Maidah turun, peristiwa ini terjadi pada tahun ke $3 \mathrm{H}$, sedangkan surat al-Maidah ayat 67 ini termasuk ke dalam surat al-Madaniyah, dengan

\footnotetext{
${ }^{42}$ Amin Suma , Studi Ilmu-ilmu alQur'an 2..., hlm. 122.
}

demikian setelah perang uhud peristiwa yang sama tidak akan terjadi lagi terhadap diri Nabi SAW, $k e d u a$, penafsiran terhadap ayat di atas perlu dilakukan dengan cara mentakdirkan kata ishmat yang diterjemahkan dengan keselamatan jiwa Nabi SAW dari kemungkinan pembunuhan yang akan dilakukan oleh musuh Islam, dalam kenyataan Nabi Saw memang tidak wafat ketika perang uhud tersebut, meskipun cidera dengan patah gigi.

3) Membandingkan penafsiran ulama dengan ulama lainnya atau membandingkan aliran tafsir dengan aliran tafsir lainnya, atau antara sunni dan syi'ah.

Setiap metode tentang penafsiran ada mempunyai keistimewaan dan mempunyai kelemahan. Adapun keistimewaan metode muqâran ini adalah lebih bersifat objektif, kritis dan berwawasan luas. Sedangkan yang menjadi kelemahan dalam metode ini terletak pada kenyataan bahwa metode muqâran tidak bisa digunakan untuk menafsirkan semua ayat Alquran sebagaimana halnya dengan metode tahlîlî dan ijmâlî.

Adapun kitab tafsir secara spesifik menggunakan metode muqâran relatif jarang atau langka, diantaranya adalah:

1) Durrat al-Tanzil wa Qurrat alTa'wil, karya al-Khatib al-Iskafi (w. $420 \mathrm{H} / 1029 \mathrm{M}$ )

\footnotetext{
${ }^{43}$ Amin Suma , Studi Ilmu-ilmu alQur'an 2..., hlm. 122.

44 Amin Suma, Studi Ilmu-ilmu alQur'an 2..., hlm. 127.
} 
2) Al-Burhan fi Taujih Mutasyabih alQur'an, karya Taj al-Qarra' alKirmani (w. 505 H/ 1111M) ${ }^{45}$

b. Maudhû' $̂$ (tematik)

Kata maudhû'î berasal dari bahasa Arab yaitu maudhu' yang merupakan isim maf'ul dari fi'il madhi wadha'a yang berarti meletakkan, menjadikan, mendustakan dan membuat-buat. ${ }^{46}$ Arti maudhu'i yang dimaksud di sini adalah judul atau topik atau sektor yang dibicarakan, sehingga tafsir maudhồ $\hat{\imath}$ berarti penjelasan tentang ayat-ayat Alquran yang berkaitan dengan satu judul/topik/sektor pembicaraan tertentu. Maudhî̀' $̂$ yang dimaksud bukan maudhû' $\hat{\imath}$ yang berarti yang didustakan atau dibuat-buat, seperti arti kata hadis maudhu' yang berarti hadis yang didustakan/dipalsukan/dibuatbuat. $^{47}$ Secara istilah pengertian tafsir maudhô'î (tematik) ialah mengumpulkan ayat-ayat Alquran yang mempunyai tujuan yang satu yang bersama-sama membahas judul/topik/sektor tertentu dan menertibkannya sedapat mungkin sesuai dengan masa turunnya selaras dengan sebab-sebab turunnya, kemudian memperhatikan ayat-ayat tersebut dengan penjelasan-penjelasan, keterangan-keterangan dan hubungan-hubungannya dengan

${ }^{45}$ Amin Suma , Studi Ilmu-ilmu alQur'an 2..., hlm. 127.

${ }^{46}$ Luis Ma'luf, Al Mun jid fr al-Lughah wa al-A`lam, Dar al-Masyriq, Beirut, 1987, hlm. 905.

Abdul Djalal, Urgensi Tafsir Maudlin'i Pada Masa Kini, Kalam Mulia, Jakarta, 1990, hlm. 83-84. ayat-ayat lain, kemudian mengistimbatkan hukum-hukum. ${ }^{48}$ Menurut al-Sadr bahwa istilah tematik digunakan untuk menerangkan ciri pertama bentuk tafsir ini, yaitu mulai dari sebuah terma yang berasal dari kenyataan eksternal dan kembali ke Alquran. la juga disebut sintesis karena merupakan upaya menyatukan pengalaman manusia dengan Alquran. ${ }^{49}$

Namun bukan berarti metode ini berusaha untuk memaksakan pengalaman ini kepada Alquran dan menundukkan Alquran kepadanya. Melainkan menyatukan keduanya di dalam konteks suatu pencarian tunggal yang ditunjukkan untuk sebuah pandangan Islam mengenai suatu pengalaman manusia tertentu atau suatu gagasan khusus yang dibawa oleh si mufassir ke dalam konteks pencariannya. Bentuk tafsir ini disebut tematik atas dasar keduanya, yaitu karena ia memilih sekelompok ayat yang berhubungan dengan sebuah tema tunggal. Ia disebut sintetis, atas dasar ciri kedua ini karena ia melakukan sintesa terhadap ayat-ayat berikut artinya ke dalam sebuah pandangan yang tersusun. ${ }^{50}$

Menurut al Farmawi bahwa dalam membahas suatu tema, diharuskan untuk mengumpulkan seluruh ayat yang menyangkut terma itu. Namun demikian, bila

${ }^{48}$ Farmawi al, Abd al-Hayy, Mu jam alAlfaz wa al-a'lam al-Our'aniyah, Dar al'ulum, Kairo, 1968, hlm. 52.

${ }^{49}$ Sadr, Muhammad Baqir, "Pendekaian Temalik Terhadap Tafsir AI-Qur'an “, dalam Ulumul Quan, Vol I, No. 4, 1990, hlm. 34.

50 Sadr, Muhammad Baqir, "Pendekaian Temalik ..., h. 34 
hal itu sulit dilakukan, dipandang memadai dengan menyeleksi ayatayat yang mewakili (representative). ${ }^{51}$ Adapun prosedur tafsri maudhû'î adalah menentukan bahasan Alquran yang akan diteliti secara tematik, melacak dan mengoleksi ayat-ayat sesuai topik yang diangkat, menata ayat tersebut secara kronologis, mendahulukan ayat-ayat makiyah dari ayat-ayat maadaniyah, mengetahui korelasi (munasabâh) ayat-ayat tersebut, melengkapi bahasan dengan hadishadis terkait, dan mempelajari ayatayat secara tematik dan konperhensif dengan cara mengkoleksi ayat-ayat yang menurut makna yang sama, mengkompromikan pengertian yang umum dan yang khusus, mutlaq dan muqayyad, mengsinkronkan ayat-ayat yang tampak kontradiktif, menjelaskan nasikh dan mansukh, sehingga semuanya memadu kedalam suatu muara, tanpa perbedaan atau pemaksaan dalam penafsiran. ${ }^{52}$

Dari beberapa gambaran di atas dapat dirumuskan bahwa tafsir maudhî' $\hat{\imath}$ ialah upaya menafsirkan ayat-ayat Alquran mengenai suatu terma tertentu, dengan mengumpulkam semua ayat atau sejumlah ayat yang dapat mewakili dan menjelaskannya sebagai suatu kesatuan untuk memperoleh jawaban atau pandangan al-Quran secara utuh tentang terma tertentu, dengan memperhatikan tertib turunnya masing-masing ayat dan

51 Farmawi al, Abd al-Hayy, $\underline{A I-}$ Bidayahfi al-Tafsir al-Maudhu'i, Matba'ah alHadarah al'Arabiyah, Kairo, 1977, hlm. 62.

52 Farmawi al, Abd al-Hayy, AIBidayahfi al-Tafsir al-Maudhu'i...,.hlm. 61-62. sesuai dengan asbabun nuzul kalau perlu.

Sama halnya dengan metodemetode tafsir yang lain, metode maudhû' $\hat{\imath}$ juga memiliki keistimewaan dan kelemahan. Adapun yang menjadi keistimewaan dari metode ini adalah penafsirannya bersifat luas, mendalam, tuntas dan sekaligus dinamis. Sedangkan yang menjadi kelemahannya adalah tidak dapat menafsirkan ayat-ayat Alquran secara keseluruhan, seperti yang telah di lakukan oleh metode ijmâlî dan tahlîli. ${ }^{53}$

Adapun diantara kitab tafsir yang menggunakan metode maudhû' î ini adalah;

1) Al-Tibyan fi Aqsam al-Qur'an, karya Ibn Qayyim al-Jauzi (691$751 \mathrm{H} / 1021-1350 \mathrm{M}$ )

2) Al-Mar'ah fi al-Qur'an, karya Muhammad al-Aqqad

3) Makanah al-Mar'ah fi Alquranal-Karim wa al-Sunnah al-Shahihah, karya Muhammad Biltaji

4) Ayat al-Ijtihadi fi AlquranalKarim Dirasah Maudhû'îyah wa Tarikhiyyah wa Bayaniyyah, karya Kamil Salamah al-Daqs

5) M. Quraiah Shihab, "Penafsiran Khalifah dengan Metode Tematik”, dalam Membumikan AI-Qur' an.

6) Nahw Tafsir Maudhû'î li Suwar Alquranal-Karim, karya Muhammad al-Ghazali. ${ }^{54}$

a. Tartib as-Suar

Berbeda dengan mudhu'I dan muqarran, tartib as-Suar ${ }^{55}$,

53 Amin Suma, Studi Ilmu-ilmu alQur'an 2...., h. 131.

54 Amin Suma, Studi Ilmu-ilmu alQur'an 2...., hlm. 131. 
merupakan langkah menafsirkan Alquran sesuai dengan urutan yang tercantum dalam mushaf Alquran, dalam hal ini yang dimaksud adalah mushaf ustmani dengan rasm ustmani. Penafsirannya dimulai dari awal surat al-Fatihah dan di akhiri dengan akhir surat an-Nash.

4. Metode tafsir dilihat dari segi perspektif (laun)

Membincangkan metode tafsir dari segi perspektif (laun)/corak. Berikut ini akan dipaparkan secara global tentang perspektif-perspektif tersebut. Dalam kamus Indonesia-Arab oleh Rasyidi dkk sebagaimana dikutib oleh Nasaruddin Baidan, kosakata "corak"diartikan dengan lauwun (warna) dan syakl (bentuk). Menurut Nasaruddin Baidan sampai sekarang belum ditemukan ulama tafsir yang menggunakan kosakata syakl dalam tafsir untuk menunjukkan makna corak, sehingga tidak ada yang berkata syakl al-Tafsir; tetapi istilah lauwun jamaknya al-Wân dapat dijumpai dalam kitab al-Dzahabî "al-Tafsir almufassirûn", seperti yang tulisnya alWân al-Tafsir fi Kulli khuthwah (corak-corak penafsiran al-Qur'an pada setiap pasenya), kemudian Nasaruddin Baidan mengomentari, pemakaian term "corak" bagi suatu penafsiran belum begitu populer apabila dibandingkan dengan term motode, sama halnya dengan bentuk tafsir. ${ }^{56}$ Selain corak dalam ilmu tafsir juga ditemukan term yang bersinonim

55 Ulama berbeda pendapat tentang tartib suar/urutan surat dalam Alquran. Ada tiga pendapat, yaitu taufiqi, ijtihadi, dan sebahagian ijtidahi serta sebahagian lagi taufiqi. Lebih lanjut lihat, Manna' al-Qatthan, Mabahist fi Ulum al-Qur'an...hal. 135-137.

${ }^{56}$ Nasaruddin Baidan, Wawasan Baru Ilmu Tafsir..., hal. 387. dengannya, yaitu ittijâh, nâhiyat, dan madrasat. Contohnya dikatakan alIttijâh Madzhabiyyah fi al-Tafsî (kecendrungan-kecendrungan aliran dalam tafsir al-Qur'an). Kosakata ittijâh mengandung arti wijhat (arah), karena kata tersebut secara etimologi memang beresal dari wijhat. Dalam kamus lisan al-'Arab kata wijhat diartikan dengan "kiblat dan semakna dengannya." Adapun pemakaian istilah nâhiyat seperti yang ditulis oleh alDzahabi "perhatian al-Zamakhsyarî terhadap aspek sastra al-Qur'an". Sedangkan pemakaian istilah madrasat al-Tafsir dapat dijumpai dalam kitab Manahij al-Qur'an oleh al-Jawnî, seperti ditulisnya "aliran kebahasaan dalam tafsir, aliran rasional dalam tafsir"

Dari sekian banyak istilah yang digunakan oleh mufassir untuk menjelaskan sosok sebuah penafsiran, maka istilah corak lebih netral dan familiar dengan budaya Indonesia karena itu lebih cenderung digunakan term corak ketimbang term yang lain. Dengan demikian Corak penafsiran adalah suatu warna, arah, atau kecenderungan pemikiran atau ide tertentu yang mendominasi sebuah karya tafsir ${ }^{58}$

Dari definisi corak tafsir di atas, untuk menentukan corak sebuah penafsiran terletak pada kata kunci dominan atau tidaknya sebuah pemikiran atau ide tersebut. Seorang teolog misalnya, penafsirannya sangat mungkin didominasi oleh pemikiran dan konsep-konsep teologis, begitu jugah faqîh penafsirannya didominasi oleh konsep-konsep fikih.

\footnotetext{
${ }^{57}$ Nasaruddin Baidan, Wawasan Baru Ilmu Tafsir..., h. 387-388

${ }^{58}$ Nasaruddin Baidan, Wawasan Baru Ilmu Tafsir..., h. 388
} 
Adapun diantara corak
penafsiran tersebut adalah sebagai berikut :

a. Tafsir Falsafì

Tafsir Falsafî adalah penafsiran ayat-ayat al-Qur'an berdasarkan pendekatan logika atau pemikiran filsafat yang bersifat liberal dan radikal. ${ }^{59}$ al-Zahabiy mendefinisikan tafsir falsafi adalah upaya pen-takwil-an ayat-ayat alQur'an sejalan dengan pemikiran filsafat atau penafsiran ayat alQur'an dengan menggunakan teoriteori filsafat. ${ }^{60}$ Kemunculan tafsir yang memiliki corak falsafî bersamaan dengan perkembangan ilmu dan science di lingkup pemerintahan Islam. Perkembangan corak falsafi di dunia tafsir dimulai pada periode penerjemahan karyakarya Yunani ke dalam bahasa Arab, yaitu pada masa khalifah Abbasiyah yang merupakan kemajuan dalam bidang ilmu pengetahuan termasuk di dalamnya ilmu filsafat. ${ }^{61}$

Penafsiran terhadap Alquran secara falsafî relatif banyak ditemui dalam sejumlah kitab tafsir yang membahas ayat-ayat tertentu yang memerlukan pendekatan secara falsafî, namun demikian secara spesifik tafsir yang menggunakan pendekatan falsafî secara keseluruahan terhadap semua ayat al-Qur'an relatif tidak begitu banyak. Diantara kitab tafsir yang menggunakan corak ini adalah

\footnotetext{
59 Amin Suma, Studi Ilmu-ilmu alQur'an 2..., h. 134

${ }^{60}$ Muhammad Husain al-Zahabi, Tafsir al-Mufassirun, (Bairut: Dar al-Fikr, t.th), Jilid II, h. 418

61 Amin Suma, Studi Ilmu-ilmu alQur'an 2..., h. 134
}

tafsir al-Qur'an al-Karim karya
Shadr al-Mutaalihin al-Siyraziy. ${ }^{62}$

b. Tafsir 'Ilmî

Tafsir 'ilmî adalah menafsirkan ayat Alquran berdasarkan pendekatan ilmiah atau menggali kandungan Alquran berdasarkan teori-teori ilmu pengetahuan. Adapun ayat-ayat yang ditafsirkan menggunakan corak 'ilmî adalah ayat-ayat kauniyah, dalam menafsirkan ayat yang berkenaan dengan ayat kauniyah para mufassir melengkapi penafsirannya dengan menggunakan teori-teori ilmiah. ${ }^{63}$ Fahd 'Abd al-Rahman mengatakan disebut dengan tafsir ilmî karena ini merupakan sebuah ijtihad mufassir untuk melengkapi hubunganhubungan ayat-ayat kauniyah di dalam Alquran dengan penemuanpenemuan ilmiah dengan tujuan untuk memperlihatkan kemu'jizatan Alquran itu sendiri. ${ }^{64}$

Mengenai tafsir 'Ilmi ada dua kelompok, yaitu kelompok yang pro dan yang kontra. Ulama yang pro terhadap tafsir 'Ilmi seperti alGhazali, al-Ghazali berpendapat bahwa segala bentuk ilmu baik yang terdahulu maupun yang datang kemudian, yang diketahui maupun yang belum diketahui semuanya bersumber dari Alquran. Ini dikarenakan segala ilmu termasuk dalam af'al Allah dan sifat-sifat-Nya. Sedangkan Alquran menjelaskan prinsip-prinsip pokoknya. Dengan demikian corak

${ }^{62}$ Ali Iyyazi, al-Mufassirun Hayatuhum wa Manahijuhum..., hal. 64

${ }^{63}$ Supiana dan M. Karman..., hal. 314.

64 Fahd 'Abd al-Rahman, Ittijah alTafsir fi al-Qur'an al-Rabi al- 'Asyr, Mamlakah al-'Arabiyah al-Su'udiyah, 1986, hal. 549. 
tafsir ilmiah tidak bertentangan dengan Alquran. ${ }^{65}$

Diantara ulama yang kontra mereka berpendapat bahwa menafsirkan Alquran dengan teoriteori ilmiah merupakan tindakan yang keliru. Allah menurunkan Alquran bukan untuk menjelaskan teori-teori ilmiah dan macammacam ilmu pengetahuan. Mengaitkan Alquran dengan ilmu pengetahuan akan mendorong pendukungnya kepada mentakwilkan Alquran agar sesuai dengan teori ilmiah. ${ }^{66}$

Berdasarkan penjelasan di atas, dengan dua kelompok ulama yang berbeda dalam menyikapi tafsir ilmî. Terlepas dari adanya pro dan kontra dalam menyikapi tafsir ilmî, penulis lebih cenderung kepada bolehnya menafsirkan Alquran dengan menggunakan corak tafsir ilmî ini dengan alasan Alquran yang diturunkan oleh Allah kepada Nabi Muhammad SAW sebagai pedoman oleh umat manusia adalah sebagai sumber dari segala ilmu pengetahuan. Karena itu menafsirkan Alquran dengan cara ilmiah adalah mencari relevansi Alquran dengan teoriteori ilmiah yang ditemukan oleh para ahli. Diantara contoh tafsir yang menggunakan corak tafsir ilmî adalah, Al-Jawahir fi Tafsir alQur'an, karya Thanthawi Jawhari ( 1287-1358H), Al-Tafsir al-Ilmi li al-Ayat al-Kawniyah fi al-Qur'an, karya Hanafi Ahmad, dan Tafsir
Ayat Kawniyah, karya Abdullah Syahatah $^{67}$

\section{c. Tafsir Tasawuf}

Tafsir Tasawuf adalah corak penafsiran Alquran yang beraliran Tasawuf. Ali Iyazi berpendapat tafsir tasawuf atau di sebut juga dengan tafsir sufi adalah corak yang berpegang kepada kearifan seorang sufi dengan rasa yang di perolehnya, yang diperolehnya dari kondisi pelatihan ruhiyah (riyadhah al-Ruhiyyah), yaitu dengan perkiraan jiwa, al-Kasy al-Bathin dan pandangan hati dengan tanpa ada hubungan antara zhahir aya. ${ }^{68}$

Dengan demikian ada kekhususan pada tafsir yang bercorak Tasawuf atau sufi ini yaitu mereka mentakwilkan Alquran dengan isyarah dan mereka tidak mengambil penafsiran terhadap Alquran seperti yang ditafsirkan oleh kebanyakan orang yang telah menafsirkan Alquran.

Ignez Goldzhiher misalnya berpendapat bahwa penafsiran dengan menggunakan corak Tasawuf telah dilakukan semenjak zaman dahulu dangan artian sama tuanya dengan Tasawuf itu sendiri. Sebelum tafsir dengan corak Tasawuf dihimpun yang disusun dengan cara berurutan secara metode, dibeberapa kalangan tentu telah terdapat berbagai bentuk aliran kebatatinan yang berpegang kepada keyakinan bahwa Alquran mencakup ajaran-ajaran yang jauh lebih kaya dari pada apa yang

\footnotetext{
65 Al-Ghazali, Ihya' 'Ulum al-Din, Semarang: Toha Putra, t.th, juz I, hal. 290

66 Al-Farmawi, Metode Tafsir Maudhui..., hal. 34.
}

\footnotetext{
67 Amin Suma, Studi Ilmu-ilmu alQur'an..., hal. 137.

${ }^{68}$ Ali Iyyazi, al-Mufassirun Hayatuhum wa Manahijuhum,... hal. 60.
} 
diajarkan menurut lahirnya. ${ }^{69}$ Diantra kitab tafsir yang mempunyai corak tasawuf adalah lathaîf al-Isyarâ, karya 'Abd alKarim bin Hawâzân al-Qusyairî (w. $434 \mathrm{H}$ ), Rahmah min al-Rahmân fi Tafsir wa Isyarât al-Qur'an, karya Mahyuddin 'Arabî (w. 638H)

Dengan penjelasan di atas maka karakteristik corak tafsir Tasawuf adalah menafsirkan Alquran dengan memahami mana batin ayat tanpa mengabaikan makna zhahir ayat. Ini dikarenakan menurut mereka (sufi) makna yang terkandung dalam batin ayat jauh lebih kaya dari makna zhahir ayat.

d. Tafsir Fiqh (fiqih)

Tafsir Fiqh adalah corak tafsir yang mempunyai orientasi pada fiqih dan hukum Islam. $^{71}$ Amin Suma mengatakan tafsir fiqh ialah tafsir yang lebih berorientasi kepada ayat-ayat hukum dalam alQur'an (ayat ahkâm). ${ }^{72}$ Menurut penulis penafsiran Alquran yang menggunakan corak fiqh biasanya dilakukan oleh ulama-ulama yang ahli dalam bidang fiqh. Dalam praktiknya ada mufassir yang menafsirkan Alquran secara keseluruhan dengan mengikuti sistematika penulisan Alquran, namun demikian mereka lebih fokus kepada pembahasan ayat-ayat yang bernuangsa hukum. Disamping itu ada juga ulama yang hanya memfokuskan pembahasan

${ }^{69}$ Ignez Gold Zhiher, Mazahib al-Tafsir al-Islamiy, Bairut: Dar Iqra', 1983, cet ke-3, hal. 238

${ }^{70}$ Ali Iyyazi, al-Mufassirun,... hal. 833.

71 Sipiana dan M. Karrman, Ulumul Qur'an ... hal. 308.

72 Amin Suma, Studi ilmu-ilmu alQur'an,... hal. 139 terhadap ayat-ayat hukum saja dengan meninggalkan pembahasan ayat yang lain.

Kehadiran corak tafsir fiqh ini karena ada asumsi bahwa Alquran dilihat dari sisi hukum adalah sebauah kitab sumber hukum. Corak ini terlahir bersamaan dengan tafsir bi al-Ma'tsur. ${ }^{74}$ Dengan demikian secara praktis dapat dikatakan bahwa corak tafsir fiqh ini sudah ada semenjak masa Rasulullah SAW yang sejalan dengan perkembangan fiqh, dan kebutuhan sahabat terhadap hukum juga memicu untuk mencarinya dalma Alquran, jika mereka kesulitan dalam memahami teks Alquran mereka langsung bertanya kepada Rasulullah SAW

Sesui dengan perkembangannya maka lahirlah kitab-kitab tafsir yang menggunakan corak fiqh, diantra kitab yang menggunakan corak ini adalah; Ahkam al-Qur'an yang disusun oleh al-Imam Hujjaj alIslam Abi Bakr Ahmad bin Ali alRazi al-Jashshash (305-370 H / 917-980 M), Ahkam al-Qur'an ibn Arabi, yang ditulis oleh Abi Bakr Muhammad bin Abdillah yang populer disebut dengan ibn Arabi (468-543 H / 1075- 1148 M), Ahkam al-Qur'an al-Kiya al-Harai, karya al-Kiya al-Harasi (w. $450 \mathrm{~h} /$ $1058 \mathrm{M}){ }^{75}$ dan lain-lain.

e. Tafsir al-Adab al-Ijtima'̂̂ 
Tafsir al-Adab al-Ijtima'î jika dilihat dari segi bahasa terdiri dari kata tafsir, al-Adab, dan al-ijtima'I. kata al-Adab merupakan mashdar dari kata adaba yang mempunyai arti sopan santun, tata karma dan sastra. ${ }^{76}$ Secara etimologi tafsir alAdab al-Ijtima'I adalah tafsir yang berorientasi pada sastra dan budaya dan kemasyarakatan. Mu'in Salim memahami tafir ini dengan pendekatan sosio kultural. ${ }^{77} \mathrm{Al}-$ Farmawi menjelaskan tafsir alAdab al-Ijtima'î adalah corak tafsir yang menitik beratkan penjelasan ayat-ayat Alquran pada aspek ketelitian redaksinya, lalu menyusun kandungan Alquran dalam redaksi yang indah dengan menonjolkan aspek-aspek petunjuk Alquran dalam kehidupan, serta menghubungkan pengertian ayat tersebut dengan hukum alam yang berlaku dalam masyarakat dan pembangunan dunia. ${ }^{78}$

Berdasarkan pengertian di atas maka tafsir al-Adab al-Ijtima'̂ิ dapat dikatakan sebuah tafsir yang menjelaskan isi kandungan Alquran dengan mengungkap keindahan isi kandungan Alquran itu sendiri, dan mengungkap persoalan-persoalan yang terjadi dalam masyarakat dengan memberikan solusi dalam mengatasinya. Dengan demikian sesuailah dengan ungkapan Abduh yang dikutip M. Quraish Shihab dalam bukunya Metode

${ }^{76}$ Louis Ma'luf, al-Munjud fi al-Lughah wa al-Adab wa al-Ulum, Bairut: Dar alMasyriq, 1986, hal. 5.

${ }^{77}$ Abd al-Mu'in Salim, Kosepsi Kekuasaan Politik dalam al-Qur'an, Jakarta; Raja Grapindo Persada, 1994, hal. 2.

78 Al-Farmawi, Metode Tafsir Maudhui..., hal. 41-42.
Penyusunan Tafsir Yang Berorientasi Pada Sastra Budaya Dan Kemasyarakatan, bahwa corak tafsir ini berusaha menjelaskan persoalan-persoalan masyarakat sebagaimana yang terkandung dalam tujuan Alquran itu diturunkan. $^{79}$

Corak tafsir ini muncul karena berkembangnya masyarakat dan dengan perubahan zaman tentunya seorang mufassir menafsirkan Alquran sesuai dengan situasi ketika ia menafsirkan Alquran, dan dengan kecendrungan spesialisasi keilmuan yang dimiliki oleh seorang mufassir itu. Diantara kitab tafsir yang menggunakan corak ini adalah; Al-Kasyâf 'an Haqâiq ghawâmid al-Tanzîl wa "uyûn alAqâwîl fi Wujûh al- Takwîl, karya Jarullah Mahmud al-Zarkhasy (w. 538 H), Al-Mahr al-Wajiz, karya Muhammad bin Abdilhaq bin 'Athiyah ( w. s 542 H), dan Majmu' al-Bayân fi Tafsir al-Qur'an, karya al-Fadhil bin al-Hasan al-Thabrasy (w. $543 \mathrm{H})^{80}$

Dari bentuk-bentuk corak penafsiran di atas dapat dikelompokkan menjadi tiga bentuk; pertama, apabila sebuah kitab tafsir mengandung banyak corak (minimal tiga corak) dan keseluruhannya tidak ada yang dominan, karena porsinya sama, maka bentuk seperti ini disembut dengan corak umum. Kedua, apabila ada satu corak yang dominan, maka itu disebut dengan corak khusus. Ketiga, apabila ada yang dominan itu dua buah corak

79 M. Quraish Shihab, Metode Penyusunan Tafsir Yang Berorientasi Pada Sastra Budaya Dan Kemasyarakatan, Ujung Pandang: IAIN Alaudin, 1984, hal. 1.

${ }^{80}$ Ali Iyyazi, al-Mufassirun Hayatuhum wa Manahijuhum,... hal. 840. 
bersamaan yakni kedua-duanya mendapat porsi yang sama, maka bentuk seperti ini disebut dengan corak kombinasi. Namun untuk menentukan pemakaian bentuk, metode, corak tafsir, seorang mufassir mempunyai kebebasan penuh. Artinya adalah sekalipun dia seorang ahli hadis misalnya, namun tafsirnya boleh saja memakai bentuk al-Ra'yi, seperti tafsir al-Jalalain juz I menggunakan bentuk bi al-Ra'yi dengan metode ijmâlî dan corak umum padahal pengarangnya adalah al-Suyûthî yang merupakan alhi hadis ternama. ${ }^{81}$

\section{Metode Penelitian Tafsir}

Metode penelitian tafsir, terdiri dari tiga kata yaitu metode, penelitian, dan tafsir. Pengertian metode sudah dibahas pada bagian sebelumnya. Penelitian adalah suatu investigasi yang terorganisir untuk menyajikan suatu informasi dalam upaya memecahkan masalah. $^{82}$ Langkah-langkah penlitan menurut Sudaryono, yaitu mengidentivikasi masalah, merumuskan dan membatasi masalah, melakukan studi kepustakaan, merumuskan hipotesis atau pertanyaan penelitian, menentukan desain dan metode penelitian, menyusun instrument dan mengumpulkan data, menganalisa data dan menyajikan hasil, dan menginterpretasikan temuan, membuat kesimpulan dan saran. $^{83}$ Sedangkan kata tafsir secara bahasa adalah masdhar (kata benda transitif)

\footnotetext{
${ }^{81}$ Nasaruddin Baidan, Wawasan Baru Ilmu Tafsir,... hal. 388-389.

${ }^{82}$ Pengertian ini dikemukakan oleh Hermawan sebgaimana dikutip oleh Sudaryono. Lebihh lanjut Lihat. Sudaryono, Metodologi Penelitian, Jakarta: Rajawali Pers, 2017, hal. 53.

${ }^{83}$ Sudaryono, Metodologi

Penelitian,..., hal. 57-59.
}

dari kata "fassara", yang setimbangan dengan kata "taf'il". Tafsir berarti menjelaskan (al-Idhah) dan menerangkan (al-tabyin). Terkait hal ini, Allah berfirman dalam surat alFurqan : ayat 33, yakni:

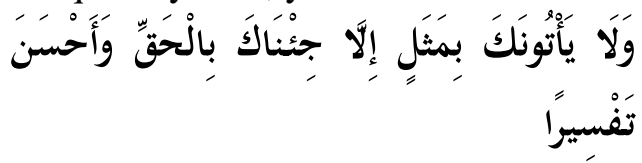

"Tidaklah orang-orang kafir itu datang kepadamu (membawa) sesuatu yang ganjil, melainkan Kami datangkan kepadamu suatu yang benar dan yang paling baik penjelasannya" [Qs. AlFurqan: 33]

Sedangkan tafsir menurut istilah adalah keterangan atau penjelasan tentang ayat-ayat Alquran atau kitab lain sehingga jelas maksudnya. ${ }^{84}$ Nasaruddin Baidan mengatakan tafsir Alquran adalah penjelasan atau keterangan terhadap maksud yang sukar memahaminya dari ayat-ayat Alqurann. ${ }^{85}$ Setelah menjelaskan pengertian dari masing-masing kata metode penelitan tafsir. Berikut ini akan disajikan metode apa yang digunakan oleh peneliti tafsir dalam meneliti tafsir?

Metode penelitian, secara umum terbagi dua yaitu, metode kualitatif dan metode kuantitatif. Dalam tulisan ini penulis hanya menjelaskan metode kualitatif, karena metode ini yang cocok dalam penelitian tafsir. Metode kualitatif adalah jenis penelitian yang menghasilkan penemuan-penemuan yang tidak dapat dicapai (diperoleh) dengan prosedur-prosedur statistika atau cara-cara lain dari kuantifikasi

${ }^{84}$ Tim Penyusun, Kamus Besar Bahasa Indonesia, cet. Ke.I, Jakarta: Balai Pustaka, hal. 992.

85 Nasaruddin Baidan, Wawasan Baru Ilmu Tafsir, Yogyakarta: Pustaka Pelajar, 2005, Cet.ke II, hal. 67. 
(pengukuran). ${ }^{86}$ Penelitian kualitatif menurut Judith dalam Cresswel, J. sebagaimana dikutip oleh Pupu Saiful Rahmad dalam tulisan jurnalnya yang berjudul penelitian kualitatif berikut.

Qualitative research is a loosely defined category of research designs or models, all of which elicit verbal, visual, tactile, olfactory, and gustatory data in the form of descriptive narratives like field notes, recordings, or other transcriptions from audio and videotapes and other written records and pictures or films. ${ }^{87}$ (Penelitian kualitatif adalah kategori desain atau model penelitian yang didefinisikan secara longgar, yang semuanya menghasilkan data verbal, visual, tactile, penciuman, dan gustatory dalam bentuk narasi deskriptif seperti catatan lapangan, rekaman, atau transkrip lainnya dari rekaman audio dan video dan tulisan lainnya. catatan dan gambar atau film.)

Dari pengertian di atas, dapat dipahami bahwa metode penelitian kualitatif digunakan untuk meneliti tentang kehidupan masyarakat, sejarah, tingkah laku, organisasi, aktivitas sosial, dan teks, termasuk juga meneliti teks-teks tafsir. Metode kualitatif digunakan untuk dapat mengetahui, menemukan dan menemukan apa yang tersembunyi dalam teks yang diteliti, baik teks berhubungan dengan sejarah, tingkah laku, social, maupun teks kitab suci. Penelitian kualitatif salah satu

\footnotetext{
${ }^{86}$ Definisi ini dekemukakan oleh Straus dan Corbin dalam Cresswell, J, sebagaimana dikutip oleh Pupu Saiful Rahmad dalam tulisannya yang berjudul Penelitian Kualitatif, Pupu Saiful Rahmad Penelitian Kualitatif, Equilibrium, Vol. 5, No. 9, Januari-Juni 2009: $1-8$

87 Pupu Saiful Rahmad Penelitian Kualitatif, Equilibrium, Vol. 5, No. 9, JanuariJuni 2009: 1-8
}

prosedur penelitian yang menghasilkan data deskriptif prilaku ucapan atau tulisan (teks) terhadap objek penelitian.

Dasar teoritis pendekatan penelitian kualitatif, yaitu pendekatan fenomenologis (berusaha memahami arti peristiwa dan kaitannya dengan orang-orang tertentu), pendekatan ineraksi simbolik (objek orang, situasi dan peristiwa tidak memiliki pengertian sendiri), pendekatan kebudayaan (untuk mengembangkan kebudayaan menurut perspektif peneliti), dan pendekatan etnometodologi (bagaimana masyarakat memandang, menjelaskan, dan menggambarkan tata hidup mereka sendiri). ${ }^{88}$ Ciri-ciri kualitatif adalah data yang dikumpulkan dalam kondisi asli atau alamiah, peneliti sebagai alat peneliti, pengumpulan data secara deskriptif, lebih mementingkan proses dari pada hasil penelitian, mencari latar belakang tingkah laku, menggunakan metode trigulasi, mementingkan rincian kontekstual, subjek yang diteliti berkedudukan sama dengan peneliti, mengutamakan perspektif emik (mementingkan pandangan responden), verifikasi melalui kasus yang bertentangan, pengambilan sampel secara purposive, menggunakan audit trail, mengadakan analisis sejak awal penelitian, dan teori bersifat dari dasar. $^{89}$

Dalam penelitian tafsir yang menjadi objek penelitiannya adalah ayat-ayat Alquran. Data yang digunakan dalam penelitian tafsir adalah data kualitatif. Berdasarkan ini,

88 Pupu Saiful Rahmad Penelitian Kualitatif, Equilibrium, Vol. 5, No. 9, JanuariJuni 2009: 1-8

${ }^{89}$ Pupu Saiful Rahmad Penelitian Kualitatif, Equilibrium, Vol. 5, No. 9, JanuariJuni 2009: 1-8 
maka metode peneitian tafsir termasuk kedalam metode kualitatif. Data yang dimaksud dalam penelitian tafsir, mengunakan metode kualitatif adalah; Ayat-ayat Alquran, hadis-hadis dan sunnah Nabi SAW, atsar shabah, pendapat-pendapat para ulama, riwayat yang merupakan, sejarah pada masa turunnya Alquran (asbab al-nuzul). pengertian-pengertian bahasa dan lafaz Alquran, kaedah-kaedah bahasa, kaedah-kaedah istinbat, dan teori-teori ilmu pengetahuan ${ }^{90}$ Setelah mengumpulkan data, langkah selanjutnya adalah menganalisis data. Langkah-langkah untuk menganalisis data dalam penelitian tafsir adalah sebagai berikut.

Pertama, untuk menganalisa ayat meliputi; kosa kata Qurani, frase qurani, klausa qurani, ayat-ayat Alquran, dan hubungan antara bagianbagian tersebut. Kedua, menginterpretasi data dengan teknikteknik yang relevan, dengan mengunakan salah satu teknik (menjelaskan ayat dengan ayat, menjelaskan ayat dengan hadis, menjelaskan ayat dengan atsar sahabat, menjelaskan ayat dengan makna lughawi, menjelaskan ayat dengan mengunakan kaidah bahasa Arab, menerangkan kandungan ayat dengan memperhatikan munasabah (korelasi) ayat, menjelaskan kandungan ayat dengan kenyataan sejarah, menjelaskan ayat dengan kaidah ushul fiqh, menjelaskan kandungan ayat dengan kaidah ulum al-Qura'n, menjelaskan makna ayat dengan kaidah logika, menjelaskan Alquran dengan ilmu pengetahuan. Ketiga proses membandingkan objek yang dapat

90 Abd Mun'im Salim, Metode Penelitian Tafsir, Ujung Pandang: IAIN Aluddin, 1994, hlm. 8-9. dikelompokkan; taufî̀, dilakukan terhadap konsep yang tidak mengandung pertentangan, tarjîh untuk menguatkan salah satu konsep, dan tawaquf meninggalkan masing-masing konsep yang bertentangan karena derajatnya seimbang. Keempat, tansîq yaitu menyusun konsep-konsep menjadi sebuah terori atau menyusun teori-tori menjadi sebuah pemikiran yang diperlukan dalam pemecahan masalah dalam penelitian. Kelima, penulisan laporan penelitian. ${ }^{91}$

\section{Kesimpulan}

Pertama, metode-metode dalam penulisan terhadap teks Alquran meliputi; sumber, intensitas, langkah dan perspektif/corak (laun). Metode tafsir dari segi sumber terbagi dua yaitu bi al-Ma'tsur dan bi al-Ra'yi. Metode tafsir dari segi intensitasnya terbagi kepada ijmali dan tahlili. Metode tafsir dari segi langkah terbagi pada muqarran, maudhu'I,dan tartib suar. Dan metode tafsir dari segi perspektif terbagi kepada fiqh, falsafi, sufi, 'ilmi dan lain sebagainya. Kedua, metode dalam penelitian tafsir adalah metode kualitatif, karena metode ini yang sesuai untuk meneliti tafsir. Objeknya jelas ayat-ayat Alquran, data yang diperlukan juga jelas ayat-ayat Alquran, hadis/sunnah, atshar sahabat, pendapat para ulama, dan sebaginya.

\section{Daftar Kepustakaan}

A. J. Weinsinck, "Israil", dalam Houtsma, et.al., 1987. Brill's First Encyclopedia of Islam 1913-1936, Leiden: E. J. Brill.

91 M. Alfatih Suryadilaga, dkk, Metodologi ilmu tafsir, Yogyakarta: Teras, cetakan ke III 2010, hlm. 153-156. 
Abu Zayd,Nasr Hamid. 2000. Mafh $m$ al-Nāsh; dirāsant fi 'Ul $m$ alQur'ān, Bairut: al-Markaz alSaqāfi al-'Arābi.

Baidan, Nasaruddin. 2002. Metodologi Penafsiran al-Qur'an, Yogyakarta: Pustaka Pelajar, cet ke-I.

Djalal, Abdul. 1990. Urgensi Tafsir Maudlin'i Pada Masa Kini, Kalam Mulia, Jakarta.

Fuad Hasan dan Koentjaraningrat, 1977. Beberapa asa Metodologi Ilmiah, Jakarta: Gramedia.

al-Farmawiy, Abd al-Hayy $1968 \mathrm{Mu}$ jam al-Alfaz wa al-a'lam alOur'aniyah, Dar al-`ulum, Kairo.

1977. al-Bidayah fi alTafsir al-Maudhu'i, Kairo: Hadrat al-Gharbiyah.

Hanafi, Hasan. 1991. Religious Dialogue and Revolition, (Dialog Agama dan Revolusi) terj. Tim Pustaka Firdaus, Jakarta: Pustaka Firdaus,

Hans-Gorg Gadamer, 2006. Classical and Philosopical Hermeneutics, dalam Teory, Culture and Socity, London: SAGE, Vol 23 (1),

al-Hadi, 2002. Ta'wil sebagai Asas Teori Sastra dan Bentuk Hermeneutika Islam, Jurnal Universitas Paramadina Vol. 1 No 2 Januari.

al-Husaynî, Khalaf Muhammad. 1974. Al-Yahûdiyyah bayn alMasîhiyyah wa allslâm , Mesir: Al-Mu'assasah alMisriyyah al-'Âmmah, 1974,
Ihde, Don, 1971. Hermeneutic Phenomenology: The Philosopy od Paul Ricoeur, Evaston, Noerthwestern University Press.

Ja'far, Musâ‘id Muslim 'Abd al-Lâh Alî. 1984. Asrâr alTathawwur al-Fikr fî alTafsîr, Beirut: Mu'assasah al-Risâlah.

M. Alfatih Suryadilaga, dkk, 2010. Metodologi Ilmu Tafsir, Yogyakarta: Teras, cetakan ke III.

Ma'luf, Luis. 1987. Al Mun jid fr alLughah wa al-A'lam, Dar alMasyriq, Beirut.

Musbikin, Imam. 2006. Istanthiq alQur'an; Pengenalan Studi alQur'an Pendekatan Interdispliner, Madiun: Jaya Star Nine.

Musthafa, Ibrahim. T.th. al-Mu'jam alWasith, Taheran: al-Maktabah al- Islamiyah.

Pasca Sarjana IAIN Sunan Ampel, 2007. Buku Penunjang Berkenaan dengan Fenomenologi dan Hermenuitik, Surabaya.

Pupu Saiful Rahmad Penelitian Kualitatif, equilibrium, Vol. 5, No. 9, Januari-Juni 2009

al-Qaththân, Mana' Khalîl. 2007. Mabâhits fi 'Ulûm al-Qur'ân, Al-Qahirah: Maktabah Wahbah,

al-Rûmiy, Fahd 'Abd al-Rahmân Sulaimân. t.th. Buhust fi Ushul al-Tasfsir, t.tp, Maktabah Al-Taubah

al-Sayûthî, Jalâl al-Dîn al-Mahallî dan Jalâl al-Dîn. t.th. Tafsîr al- 
Qur'ân al- 'Azhîm, Beirut: Syamsuddin, Sahiron. 2017. Dâr al-Fikr. Hermeneutika dan

al-Syirbâshî, Ahmad. 1972. Qishshah al-Tafsîr, Beirut: Dâr alQalam.

Sadr, Muhammad Baqir, 1990. "Pendekaian Temalik Terhadap Tafsir AI-Qur'an “, dalam Ulumul Quan, Vol I, No. 4.

Saleh, Ahmad Syukri, 2007. Metodologi Tafsir al-Qur'an Kontemporer Dalam Pandangan Fazlur Rahman, Jambi: Sultan Thaha Press, cet ke-2

Pengembangan

Ulumul

Qur'an, Yogyakarta: Pesantren Nawesea Press.

Syamsudin, Sahiron. 2011. Hermenetika Hans-georg Gadamer dan Pengembangan Ulumul Qur'an dan Pembacaan Alquran Pada Masa Kontemporer, dalam Upaya Intergrasi Hermeneutika dalam Kajian Qur'an dan Hadis Teori dan Aplikasi, Yogyakarta: Lembaga Penelitian UIN Sunan Kali Jaga, cet II,

Salim, Abd Mun'im. 1994. Metode Penelitian Tafsir, Ujung Pandang: IAIN Aluddin.

Sudaryono, 2017. Metodologi Penelitian, Jakarta: Rajawali Pers.

Suma, Muhammad Amin, 2001 Studi Ilmu-ilmu al-Qur'an 2, Jakarta: Pustaka Firdaus, 2001.

Supiana dan M. Karman, 2002. Ulumul Qur'an dan Pengenalan Metodologi Tafsir, Bandung: Pustaka Islamika, cet.I.

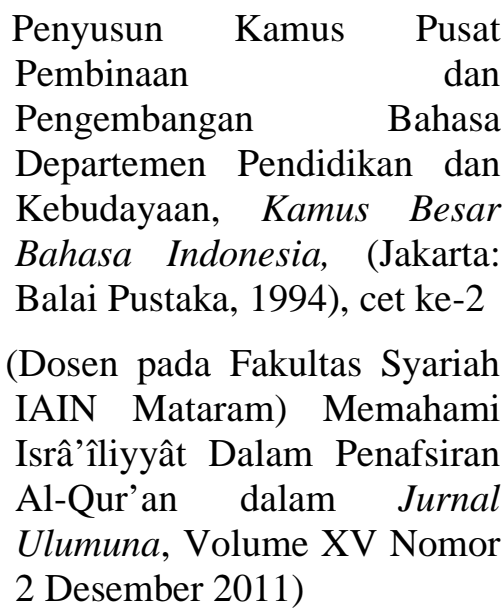

Zakariya, Ahmad bin Faris bin. 1990. Mu'jam Maqais al-Lughah, (Mesir: 'Isa al-Babi al-Habi. 
66 Jurnal Ulunnuha Vol.7 No.1/Juli 2018 